\title{
TANTANGAN PERGURUAN TINGGI DALAM ERA PERSAINGAN GLOBAL
}

\author{
M. Kadarisman \\ kadarisman.bkn@gmail.com
}

\begin{abstract}
The university's challenge in the era of globalization is characterized by the development of science and technology which is full of competition. Sooner or later, universities in Indonesia in the future will face challenge to improve quality of educational institutions that must produce qualified human resources and advantages in various aspects of life. College is one of the subsystems of national education that cannot be separated from other subsystems within and outside the education system. Universities are able to develop at least five forms of intelligence, namely intellectual, emotional intelligence, practical intelligence, social intelligence and spiritual intelligence as well as moral. The five forms of this intelligence must be developed simultaneously. If well done, then not only produce students and graduates who are intellectually smart, but also smart in other things.
\end{abstract}

Keywords: Globalization of Education, Science, Quality of Human Resources.

\section{Pendahuluan}

Perkembangan masyarakat industri dan pasca industri di beberapa belahan dunia, terutama di daratan Eropa dan Amerika, telah berpengaruh luas kepada masyarakat global di seluruh dunia, sehingga merubah tatanan hidup mereka dalam segala bidang kehidupan, yang kemudian disebut dengan globalisasi (Beck, 2000). Globalisasi adalah proses saling hubungan yang mendunia antar individu, bangsa dan negara serta berbagai organisasi kemasyarakatan. Proses itu terjadi karena adanya alat komunikasi dan transportasi yang berteknologi canggih, dibarengi kekuatan-kekuatan politik dan ekonomi serta nilai-nilai sosial budaya yang saling mempengaruhi. Satu nilai budaya tertentu, tidak bisa menutup diri dari nilai budaya yang lain meskipun diproteksi sedemikian rupa, sehingga terjadilah pertukaran budaya antara budaya satu komunitas dengan komunitas yang lainnya.

Di antara faktor yang mendorong terjadinya globalisasi adalah (Scott, 1988) pertama, hakikat manusia sebagai homo sosial; kedua kebutuhan ekonomi, dan ketiga tersedianya sarana komunikasi dan transportasi modern. Ketiga faktor tersebut berkaitan erat satu sama lain dan mendorong terbentuknya berbagai wadah kerja sama regional dan global, terutama dalam bidang ekonomi, seperti ASEAN (Association of South-East Asian Nations), AFTA (Asian Free Trade Area), dan WTO (World Trades Organization). Globalisasi menyebabkan persaingan dalam bidang ekonomi semakin keras dan ketat, tetapi selalu berada dalam ruang lingkup kerja sama. Istilah yang semakin populer ialah "bersaing dengan" (compete 
with), yang mengimplikasikan adanya kerja sama, dan bukan "bersaing terhadap"(compete against) yang mengimplikasikan persaingan bebas seperti yang terjadi pada beberapa dekade terdahulu pada abad ke-20.

Dalam persaingan itu kemenangan akan ditentukan, terutama oleh mutu Sumber Daya Manusia (SDM). Perubahan mendasar yang ditimbulkan oleh globalisasi ialah keterbukaan, yang mengimplikasikan demokrasi dan kebebasan, baik dalam diri individu maupun masyarakat serta pengelolaan negara dan bangsa. Apabila manusia menutup dirinya, pergaulannya akan terbatas dan pengalaman solidaritas sosialnya sulit berkembang. Demikian juga halnya dengan bangsa dan negara. Kemajuan tidak akan tercapai, apabila suatu negara tidak membuka dirinya terhadap bangsa- baugsa lain dalam pergaulan internasional. Era globalisasi akan ditandai dengan persaingan ekonomi secara hebat berbarengan dengan terjadinya revolusi teknologi informasi, teknologi komunikasi, dan teknologi industri. Persaingan ini masih dikuasai oleh tiga raksasa ekonomi yaitu Jepang dari kawasan Asia, Uni Eropa dan Amerika Serikat. Masing-masing menampilkan keunggulan yang dimiliki (Scott, 1988).

Amerika misalnya unggul dalam product technology, yaitu teknologi yang menghasilkan barang-barang baru dengan tingkat teknologi yang tinggi, contoh pembuatan pesawat terbang supersonik, robot, dan lain-lain. Jerman dan Jepang mengandalkan kelebihan mereka dalam process technology yaitu teknologi yang menghasilkan proses baru dalam pembuatan suatu jenis produk yang sudah ada, misalnya compact disc (CD) pertama kali dibuat oleh Belanda kemudian terus disempurnakan oleh Jepang sehingga menghasilkan CD dengan kualitas yang lebih bagus dan harga lebih murah. Selain ketiganya, belakangan muncul Cina sebagai kekuatan baru ekonomi dunia dengan pertumbuhan ekonominya di atas 9 persen, suatu jumlah tertinggi di dunia. Kompetisi ekonomi pada era pasar bebas juga ditandai dengan adanya perjalanan lalu lintas barang, jasa, modal serta tenaga kerja yang berlangsung secara bebas, kemudian adanya tuntutan teknologi produksi yang makin lama makin tinggi tingkatannya, sehingga makin tinggi pula tingkat pendidikan yang dituntut dari para pekerjanya.

Kemudian dalam perkembangan selanjutnya, kemajuan teknologi komunikasi menyebabkan tidak adanya jarak dan batasan antara satu orang dengan orang lain, kelompok satu dengan kelompok lain, serta antara negara satu dengan negara lain. Komunikasi antar-negara berlangsung sangat cepat dan mudah. Begitu juga perkembangan informasi lintas dunia dapat dengan mudah diakses melalui teknologi informasi seperti melalui internet. Perpindahan uang dan investasi modal oleh pengusaha asing dapat diakukan dalam hitungan detik. Kondisi kemajuan teknologi informasi dan industri yang berlangsung dengan amat cepat dan ketat di era globalisasi, menuntut setiap negara untuk berbenah diri dalam menghadapi persaingan tersebut. Pesatnya perkembangan teknologi informasi misalnya, merupakan salah satu ciri utama perkembangan global di abad 21 ini. Siap atau tidak siap hal itu merupakan satu realitas yang harus dihadapi dengan kualitas SDM dengan daya saing unggul (Jarvis, 2001). 
Dalam era globalisasi, setiap orang dituntut untuk mampu mengatasi berbagai masalah yang kompleks sebagai akibat pengaruh perubahan global. Memasuki abad ke-21 ada empat kecenderungan perubahan yang akan mempengaruhi pola-pola kehidupan yaitu pertama, perubahan lingkungan ekonomi, sosial dan pengetahuan dan teknologi; kedua, perubahan dalam lingkungan kerja; ketiga, perubahan dalam harapan pelanggan; dan empat, perubahan harapan para pekerja. Dengan demikian, pada tatanan global ini seluruh umat manusia di dunia dihadapkan pada tantangan yang bersumber dari perkembangan global sebagai akibat pesatnya perkembangan ilmu pengetahuan dan teknologi. Dalam kaitan ini diidentifikasi adanya sepuluh tantangan di abad 21 yaitu 1. kecepatan (speed), 2. kenyamanan (convenience), 3. gelombang generasi (age wave), 4. pilihan (choice), 5. ragam gaya hidup (life style) 6. kompetisi harga (discounting), 7. pertambahan nilai (value added) 8. pelayanan pelanggan (cpustemer service), 9. teknologi sebagai andalan (techno age), 10. jaminan mutu (quality control) (Scott, 1988).

Bangsa yang mampu membenahi dirinya dengan meningkatkan SDM-nya, kemungkinan besar akan mampu bersaing dalam kompetisi sehat tersebut. Di sinilah lembaga tinggi pendidikan, termasuk pendidikan tinggi swasta diharuskan menampilkan dirinya, apakah ia mampu mendidik dan menghasilkan para lulusan yang berdaya saing tinggi (qualified) atau justru mandul dalam menghadapi gempuran berbagai kemajuan dinamika globalisasi tersebut. Dengan demikian, era globalisasi dewasa ini adalah tantangan besar bagi dunia pendidikan khususnya di Indonesia. Dalam dunia pendidikan tinggi termasuk di Indonesia, adalah menganut faham universialisme ilmu pengetahuan dan teknologi. Kondisi demikian menunjukkan bahwa masyarakat pendidikan Indonesia, adalah bagian dari masyarakat global. Proses globalisasi seperti ini, telah berlangsung sejak lama dalam dunia pendidikan. Namun dalam perkembangan yang terjadi sejak 1970an, globalisasi berkembang menjadi "the process through which sovereign national states are criss-crossed and undermined by transnational actors- governments or MNCs-with varying prospects of power, orientations, identitities, and networks" (Jarvis, 2001).

\section{Pembahasan}

Globalisasi secara populer dimaksudkan sebagai menyebarnya segala sesuatu secara sangat cepat ke seluruh dunia. Beck, (2000) mengemukakan bahwa"globalisasi sebagai the compression of the world into a single space and the intensification of conciousness the world as a whole". Globalisasi juga melahirkan global culture (which) is encompassing the world at the international level. Globalisasi tidak hanya menyangkut dan berdampak pada bidang ekonomi, tetapi hampir seluruh elemen kehidupan manusia, maka globalisasi pun berdampak pada pendidikan tinggi dan perguruan tinggi. Tampaknya tidak akan lama lagi kekuatan dan gejalanya tidak dapat dibendung lagi. Pergerakan bebas ilmu pengetahuan dan teknologi yang merupakan salah satu aspek penting dalam globalisasi tentu akan menyentuh pula bidang pendidikan, khususnya pendidikan tinggi. 
Globalisasi dalam dunia pendidikan, adalah sebuah proses sejarah yang panjang. Terjadinya era globalisasi dalam dunia pendidikan, memberi dampak ganda yaitu dampak yang positif (menguntungkan) dan dampak yang negatif (merugikan). Dampak yang menguntungkan, adalah memberi kesempatan kerjasama yang seluas-luasnya di bidang pendidikan kepada negara-negara di dunia. Namun di sisi lain, jika Indonesia tidak mampu bersaing di bidang pendidikan dengan negara lain, karena kualitas SDM yang lemah misalnya, maka konsekuensinya akan merugikan bangsa Indonesia sendiri.

Oleh karenanya, tantangan Indonesia di bidang pendidikan pada masa yang akan datang ialah meningkatkan daya saing dan keunggulan kompetitif dengan mengandalkan pada kemampuan SDM, teknologi, dan manajemen tanpa mengurangi keunggulan komparatif yang telah dimiliki bangsa kita. Tantangan perguruan tinggi di era global adalah ditandai dengan perkembangan ilmu pengetahuan dan teknologi yang penuh dengan persaingan. Cepat atau lambat, perguruan tinggi di Indonesia yang akan datang, harus menghadapi peningkatan kualitas perguruan tinggi selaku lembaga pendidikan yang harus menghasilkan SDM yang berkualitas dan memiliki keunggulan dalam berbagai aspek kehidupan. Perguruan tinggi merupakan salah satu subsistem pendidikan nasional yang tidak dapat dipisahkan dari subsistem lainnya baik di dalam maupun di luar sistem pendidikan.

Keberadaan perguruan tinggi dalam keseluruhan kehidupan berbangsa dan bernegara, mempunyai peran yang amat besar melaui Tri Dharma Perguruan Tinggi yaitu pendidikan, penelitian dan pengabdian kepada masyarakat. Dalam Undang-Undang Nomor 20 Tahun 2003 tentang Sistem Pendidikan Nasional, pasal 20 ayat (2) dinyatakan bahwa perguruan tinggi berkewajiban menyelenggarakan pendidikan, penelitian dan pengabdian kepada masyarakat. Melalui dharma pendidikan tinggi yang pertama, perguruan tinggi harus mampu memberdayakan proses pendidikan yang sedemikian rupa agar seluruh mahasiswanya berkembang menjadi lulusan sebagai SDM berkualitas yang memiliki kompetensi paripurna secara intelektual, profesional, sosial, moral dan personal.

Dharma kedua yaitu penelitian, perguruan tinggi harus mampu mewujudkan sebagai satu institusi ilmiah akademik yang dapat menghasilkan berbagai temuan inovatif melalui kegiatan-kegiatan ilmiah berupa penelitian. Melalui penelitian tersebut, perguruan tinggi dapat mengembangkan dirinya serta memberikan sumbangan nyata bagi pengembangan bidang keilmuan dan aplikasi dalam berbagai upaya pembaharuan. Selanjutnya melalui dharma ketiga yaitu pengabdian kepada masyarakat, keberadaan perguruan tinggi harus dapat dirasakan manfaatnya bagi kemajuan masyarakat luas. Hal ini mengandung makna bahwa keberadaan perguruan tinggi di Indonesia harus dirasakan oleh masyarakat di sekitarnya dengan memberikan pemahaman kepada masyaraat sesuai dengan bidangnya.

Dalam memasuki era baru di abad 21 ini, sistem pendidikan tinggi di Indonesia harus terwujud sedemikian rupa dengan karakteristik antara lain, pertama, terkait dengan kebutuhan mahasiswa, prioritas nasional dan 
pembangunan ekonomi; kedua, terstruktur secara efektif sehingga memberi peluang kepada seluruh warga negara untuk mengembangkan potensi pribadi sepanjang hayat dan berkontribusi kepada masyarakat, bangsa dan negara; ketiga, didukung dengan pendanaan yang memadai sehingga memungkinkan untuk berinovasi dan mencapai keunggulan; keempat, melakukan penelitian yang dapat menunjang pembangunan nasional; kelima, memiliki akses dalam pengembangan dan penerapan teknologi; keenam, berperan sebagai kekuatan moral dalam mewujudkan masyarakat demokratis yang madani.

Dengan demikian, perguruan tinggi di Indonesia harus memiliki kredibilitas institusional secara utuh dan menyeluruh. Sistem ini harus memiliki akuntabilitas yang tinggi terhadap masyarakat, menunjukkan efisiensi dalam operasionalnya, menghasilkan lulusan yang berkualitas, memiliki manajemen internal yang transparan dan memenuhi standar. Dengan memperhatikan uraian di atas, dapat dikatakan bahwa perguruan tinggi di Indonesia saat ini menghadapi masalah dan tantangan eksternal yang berkaitan erat dengan globalisasi, pembangunan ekonomi, desentralisasi, situasi politik, perkembangan sosial budaya dan teknologi.

Sementara itu kenyataan objektif secara internal perguruan tinggi di Indonesia masih menghadapi berbagai tantangan dan masalah yang bersumber dari pola-pola menajemen yang sentralistik, mekanisme pendanaan yang sentralistik dan kaku, organisasi dan manajemen yang kurang efisien, kualitas SDM yang kurang memadai dan belum optimalnya partisipasi masyarakat dalam pendanaan pendidikan. Semua masalah itu memerlukan penanganan secara nasional, sistematik dan terpadu. Sehubungan dengan itu antisipasi pengembangan dan kinerja perguruan tinggi khususnya perguruan tinggi swasta, merupakan satu hal yang harus diwujudkan demi kelestarian dalam menghadapi gelombang tantangan dalam tatanan global, nasional, regional, lokal dan organisasional. Hal ini mengandung makna bahwa pengembangan perguruan tinggi, khususnya perguruan tinggi swasta, merupakan satu keharusan yang tidak dapat ditawar-tawar lagi agar menjadi lembaga pendidikan yang lestari dan bermutu.

Pengembangan perguruan tinggi di Indonesia khususnya perguruan tinggi swasta, sekurang-kurangnya mencakup aspek struktur, kultur, substansi, dan SDM. Dalam aspek struktur perlu dikaji struktur kelembagaan perguruan tinggi termasuk hubungan struktural dan fungsional antar lembaga pendidikan, dengan pemerintah pusat maupun daerah, khususnya Kementerian Pendidikan Nasional dan pihak-pihak terkait lainnya sehingga diperoleh satu struktur yang menunjang eksistensinya. Dalam aspek kultur, perlu dilakukan pola-pola budaya yang sedemikian rupa dapat menunjang berkembangnya Lembaga Pendidikan Tinggi yang bercorak khas sebagai cerminan jatidiri, visi, misi dan strategi perguruan tinggi yang bersangkutan. Budaya birokratis dan feodal harus bergeser ke budaya pedagogis yang demokratis dalam suasana nilai-nilai kejuangan dosen.

Budaya komunikasi satu arah yang top down, harus digeser menjadi budaya komunikasi dua arah dan bottom up, budaya pengaturan yang sentralistik 
ke budaya pemberdayaan dan desentralistik yang otonom. Bagaimana pun perguruan tinggi adalah merupakan aktualisasi kultur pendidikan, sehingga paradigma pendidikan harus menjadi landasan utama dalam perwujudan kinerjanya melalui aktualisasi tridharma perguruan tinggi tersebut. Teknologi informasi dan komunikasi, seperti internet dan world wide web, menyediakan peralatan baru yang dapat diandalkan dalam membentuk jaringan global untuk pengajaran dan riset. Universitas sudah tidak memonopoli produksi ilmu pengetahuan, karena harus bersaing dengan penyedia jasa informasi dan pengetahuan lainnya yang tidak memerlukan kampus dengan segala fasilitas yang mahal.

Dengan demikian, di perguruan tinggi dampak yang perlu diantisipasi dan tantangan yang perlu dihadapi paling sedikit ada tiga bidang persaingan, yaitu dalam pengelolaan perguruan tinggi, proses belajar mengajar, dan pendidikan nilai. Apabila bidang pendidikan akan disamakan dengan bidang perdagangan (barang dan jasa), maka prinsip pasar bebas harus diperlakukan pula. Artinya, setiap negara harus membuka diri seluas-luasnya terhadap masuknya perguruan tinggi, dosen, peneliti dan sebagainya tanpa hambatan sama sekali dalam bentuk apapun. Apakah dengan demikian akan terjadi persaingan antar perguruan tinggi dalam negeri dan perguruan tinggi asing? Jika demikian persoalannya siapkah perguruan tinggi lokal bersaing dengan perguruan tinggi asing?

Globalisasi ternyata mengubah cara belajar mengajar, dari bertatap muka dan melalui hubungan personal antara dosen dan mahasiswa menjadi hubungan maya dan nonpersonal, melalui internet dan video jarak jauh. Pertanyaannya apakah dengan model pembelajaran yang semacam itu pembentukan nilai-nilai disiplin dan kejuangan bisa dikembangkan? Globalisasi seringkali menghadirkan pengetahuan dan informasi berlebihan yang tidak dapat ditangkap oleh orang kebanyakan yang tidak mampu pula mencerna tantangan yang menyertainya, sehingga hidup dalam alam globalisasi merupakan resiko dan mengubah identitas seseorang, tempat tinggal, dan kehidupan masa depan (Lanqing, 2005).

Namun, gejala yang tidak dapat dihindarkan dan dibalikkan membawa pula harapan dan kesempatan baru. Globalisasi tidak dapat dikatakan baik atau buruk. Globalisasi akan menjadi seperti apa yang dikehendaki dan diperbuat oleh manusia. Oleh karena itu bagi mereka yang berfikir secara kritis, antisipatif, dan analitis, termasuk perguruan tinggi, beberapa pertanyaan mendasar berikut perlu dipikirkan (Imron, 1996): a. mampukah globalisasi menjaga nilai-nilai kemanusiaan dan sekaligus menghormati identitas budaya, tradisi, dan agama yang merupakan kekayaan warisan budaya manusia?

Selanjutnya b. mampukah globalisasi meletakkan fondasi yang lebih kuat untuk pengembangan budaya manusia yang otentik dan universal? c. dapatkah pendidikan mempertemukan berbagai budaya dan tradisi dalam hubungan satu sama lain, menanamkan semangat keberagaman, dan meningkatkan hak-hak manusia untuk memelihara identitas masing-masing? d. dapatkah pendidikan tinggi menjawab pertanyaan dan menanggapi tantangan atas kesatuan dan 
keberagaman orang dan budaya? e. teknologi mungkin mampu menjadikan perguruan tinggi bersifat global dalam jangkauannya, namun ada sesuatu yang agaknya tetap dikehendaki secara lokal, yaitu kearifan lokal, dan pemberdayaan potensi lokal. Apa artinya kemajuan yang meminggirkan potensi lokal? $\mathrm{f}$. pembelajaran berbasis internet memang menjanjikan cara baru menguasai ilmu pengetahuan, tetapi sekaligus menciptakan hambatan baru. Dalam era internet para ahli akan menjadi rebutan antara universitas, hak intelektual menjadi sangat menonjol sehingga menjurus pada privatisasi ilmu pengetahuan? g. universitas sebagai komunitas akademis dengan segala kegiatanya memberikan suasana akademis yang menunjang hasrat belajar dan meneliti. Interaksi antar mahasiswa dan antar dosen dan mahasiswa memberi sumbangan pada pembentukan watak dan pribadi mahasiswa. Apakah hal ini masih akan terjadi apabila pengajaran dilakukan melalui internet?

Namun kondisi riil di sebagian perguruan tinggi di Indonesia pada era globalisasi ini, tawuran antar mahasiswa justru sering mewarnai kehidupan kampus. Padahal, akar masalahnya hanyalah sepele. Akibat yang ditimbulkannya luar biasa parah. Korban pun berjatuhan, baik dari pihak mahasiswa sendiri maupun pihak lain yang akan melerai. Banyak yang menuduh ini ulah provokator. Tawuran menjadi tip of iceberg dari krisis yang dihadapi mahasiswa di sebagian perguruan tinggi di Indonesia. Krisis-krisis yang dihadapi perguruan tinggi di Indonesia, mahasiswa salah satunya, jelas bukan semata-mata menyangkut kinerja perguruan tinggi dalam hal kualitas akademik lulusannya, tetapi juga dalam hal mentalitas, moral, dan karakter. Dalam krisis mentalitas dan moral mahasiswa tersebut, terdapat beberapa masalah pokok yang turut menjadi akar krisis mentalitas dan moral di lingkungan perguruan tinggi.

Pertama, arah pendidikan telah kehilangan objektivitasnya. Perguruan Tinggi tidak lagi merupakan tempat peserta didik melatih diri untuk berbuat sesuatu berdasarkan nilai-nilai moral dan akhlak, yaitu mereka mendapat koreksi tentang tindakan-tindakannya; salah atau benar; baik atau buruk. Kedua, proses pendewasaan diri tidak berlangsung baik di lingkungan perguruan tinggi. Lembaga pendidikan ini cenderung lupa pada fungsinya untuk turut mendewasakan mahasiswa; mempersiapkan mereka untuk meningkatkan kemampuan merespon dan memecahkan masalah-masalah dirinya sendiri maupun orang lain.

Ketiga, proses di perguruan tinggi sangat membelenggu mahasiswa dan bahkan dosen. Hal ini karena formalisme perguruan tinggi dan beban kurikulum yang sangat berat (overloaded). Akibatnya, hampir tidak tersisa lagi ruang bagi mahasiswa untuk mengembangkan imajinasi dan kreativitas intelektualnya. Lebih parah lagi, interaksi akademis yang berlangsung hampir kehilangan human and personal touch-nya. Keempat, kalaupun ada materi yang menumbuhkan rasa afeksi, seperti matakuliah agama, itu umumnya disampaikan dalam bentuk verbalisme yang juga disertai dengan rote-memorizing. Matakuliah agama cenderung hanya untuk sekadar diketahui dan dihafalkan agar lulus ujian, tetapi tidak untuk diinternalisasikan dan dipraktekkan. 
Krisis mentalitas dan moral mahasiswa, bagaimana pun juga merupakan cermin dari krisis mentaliats dan moral dalam masyarakat lebih luas. Oleh karena itu, upaya mengatasi krisis tidak memadai jika dilakukan hanya di lingkungan perguruan tinggi, tetapi juga dalam keluarga dan lingkungan lainnya. Dalam deklarasi "World Conference on Higher Education" (UNESCO, Paris, 5-9 Oktober 1998) menyangkut misi dan fungsi untuk membantu melindungi dan memperkuat nilai-nilai yang membentuk dasar kewarganegaraan demokratis, dan dengan memberikan perspektif kritis dan membantu dalam pembahasan tentang pilihanpilihan strategis serta pengamatan perspektif humanistik. Menurut deklarasi, lembaga-lembaga pendidikan tinggi, personal perguruan tinggi dan para mahasiswa, haruslah menjaga dan mengembangkan fungsi-fungsi krusial mereka dengan pelaksanaan etika; budaya, dan sosial secara independen sepenuhnya dan sadar betul tentang tanggung jawab mereka.

Pendidikan setidaknya mampu mengembangkan lima bentuk kecerdasan, yaitu kecerdasan intelektual, kecerdasan emosional, kecerdasan praktikal, kecerdasan sosial, dan kecerdasan spiritual dan moral. Kelima bentuk kecerdasan ini harus dikembangkan secara simultan. Jika berhasil dilakukan dengan baik, akan menghasilkan mahasiswa dan lulusan yang bukan hanya cerdas secara intelektual, tetapi juga cerdas dalam hal lain. Di sinilah terletak penekanan utama proses pendidikan, seperti yang dikemukakan Deklarasi UNESCO dan paradigma baru pendidikan nasional, bahwa pendidikan harus berpusat pada peserta didik.

Oleh karena itu, adalah suatu kelemahan mendasar dalam pengelolaan negara, jika keterbukaan tidak berkembang dengan wajar. Ini berarti nasionalisme, paham etnis yang sempit dan fanatisme keagamaan sangat bertentangan dengan globalisasi. Persaingan dalam konteks kerjasama adalah salah satu paradigma konstruktif baru yang dibawa oleh globalisasi. Perubahan mendasar lainnya yang dibawa industrialisasi ialah rasionalitas, yang mengimplikasikan efektivitas dan efisiensi dalam semua segi kehidupan, termasuk penggunaan waktu. Semuanya harus diperhitungkan secara rasional. Globalisasi turut mempercepat berkembangnya masyarakat industri Indonesia dalam abad ke-21, bahkan juga masyarakat pascaindustri. Desakan percepatan itu akan sulit dikendalikan dan dapat menimbulkan berbagai kesenjangan dalam masyarakat di berbagai daerah. Rasionalitas dapat berbenturan dengan nilai-nilai tradisi yang emosional, termasuk nilai-nilai keagamaan (Friedman, 2002).

Rasionalitas juga menyebabkan dominasi rasio atau nalar dalam kehidupan manusia. Kecerdasan Intelektual atau IQ dijadikan sebagai ukuran kecerdasan manusia. Dominasi rasio ini menyebabkan melemahnya kehidupan beragama, sebagaimana dapat dilihat dari berkembangnya sekularisme di dunia Barat yang memisahkan agama dari kehidupan bernegara. Setelah Perang Dunia II, terutama sejak tahun 70-an, banyak pemikir Barat yang menyadari akibat-akibat negatif dari dominasi rasio itu. Misalnya, telah terjadi dekadensi dalam kebudayaan Barat, yang antara lain ditandai oleh semakin jauhnya individu dan masyarakat dari agama. Dominasi rasio berkembang pesat melalui pendidikan, termasuk di Indonesia. 
Hingga akhir abad ke-20 hal ini masih terlihat antara lain dari anggapan umum bahwa siswa dan mahasiswa pintar selalu mendapat nilai baik dalam pelajaran MIPA. Dalam lingkup yang lebih kecil, di Asia khususnya, globalisasi telah menyebabkan adanya asianisasi. Naisbitt (1995) meramalkan bahwa asianisasi akan terjadi, dan sesungguhnya sudah mulai terlihat dalam dekade terakhir abad ke-20. Proses ini pada dasarnya merupakan bagian dari globalisasi, yaitu pengaruh Asia, terutama Asia Timur, Selatan, dan Tenggara, semakin kuat dan rnendunia. Asia akan menjadi pusat perkembangan ekonomi, terutama karena kekayaan Sumber Daya Alama (SDA) dan jumlah SDM-nya serta kebudayaannya yang beraneka ragam dan bernilai tinggi. Perubahan mendasar yang dibawa oleh asianisasi ialah percaya diri Asia yang semakin kuat.

Bangsa-bangsa Asia tidak banyak lagi bergantung pada bangsabangsa Barat seperti pada masa lalu. Arus pengaruh bahkan akan berbalik dari Asia ke Barat. Di antara bangsa-bangsa Asia, Cina akan memainkan peranan yang lebih besar. Pengaruh globalisasi lainnya adalah sistem informasi akan semakin canggih. Hal itu sudah terlihat di Indonesia sejak dekade terakhir ke-20. Berbagai model komputer, jaringan Internet, multi media, dan berbagai macam alat komunikasi sudah ada di pasar. Akibat dari adanya alat komunikasi yang canggih ini adalah informasi akan semakin sarat makna dan arusnya semakin deras. Bahasa yang digunakan akan semakin sederhana tapi efektif dan penuh makna. Peristiwa-peristiwa yang terjadi di belahan bumi tertentu dapat disaksikan langsung oleh penduduk lain di belahan bumi yang berbeda. Kesaratderasan informasi itu akan berpengaruh besar terhadap cara pandang, cara berpikir dan cara berkomunikasi manusia (Khaerudin, 1999).

Pengaruh globalisasi yang kompleks sebagaimana yang dijelaskan di atas, tentunya tidak saja terjadi pada masalah ekonomi, politik dan budaya, akan tetapi seluruh aspek kehidupan manusia hingga dalam dunia pendidikan. Perguruan tinggi sebagai lembaga pendidikan yang ada dalam dunia global, tentunya tidak bisa terhindar dari pengaruh globalisasi dan akibat-akibatnya, sehingga perguruan tinggi tertantang harus mampu mengatasinya agar dapat bertahan dalam menjaga kelangsungan hidupnya. Setidaknya ada empat masalah besar yang kompleks yang dihadapi perguruan tinggi di era global ini (Edward, 1995). Pertama, tantangan untuk meningkatkan nilai tambah dalam rangka meningkatkan produktivitas nasional, pertumbuhan, dan pemerataan ekonomi sebagai upaya untuk memelihara dan meningkatkan pembangunan berkelanjutan.

Kedua, tantangan untuk melakukan pengkajian dan penelitian secara komprehensif dan mendalam terhadap terjadinya transformasi struktur masyarakat dari tradisional ke modern, dari agraris ke industri dan informasi, serta bagaimana implikasinya bagi pengembangan sumber daya manusia di perguruan tinggi. Ketiga, tantangan dalam persaingan global yang semakin ketat, yaitu bagaimana meningkatkan daya saing bangsa dalam menghasilkan karyakarya yang berkualitas unggul sebagai hasil penguasaan iptek dan informasi. Keempat, munculnya kolonialisme baru di bidang iptek, informasi, dan ekonomi untuk menggantikan kolonialisme politik. Semua masalah dan tantangan tersebut 
menuntut SDM Indonesia khususnya masyarakat intelektual perguruan tinggi agar meningkatkan serta memperluas wawasan pengetahuan, wawasan keunggulan, keahlian yang profesional, serta keterampilan manajerial dan kualitasnya. Yang menjadi pertanyaan selanjutnya adalah apa yang harus dilakukan perguruan tinggi untuk menghadapi tantangan-tantangan tersebut?

Di era pasar bebas pada abad 21 ini, perguruan tinggi dituntut dapat melakukan beberapa agenda kegiatan sebagai berikut (Ibe, 1995): pertama, mengantisipasi persaingan tenaga kerja yang mengglobal, yang masuk bersama penanaman modal asing sebagai konsekuensi diberlakukannya perjanjian ASEANAFTA (mulai tahun 2002), WTO-GATT dan APEC (mulai tahun 2010). Untuk antisipasi hal ini perguruan tinggi harus mampu menjamin hasil didiknya di berbagai bidang profesi untuk memperoleh sertifikat profesi sebagai syarat untuk memperoleh hak bekerja sesuai dengan kompetensi kepakaran yang dipelajarinya di perguruan tinggi. Kedua, perguruan tinggi harus mampu menyiapkan hasil didik yang kompetensinya dinilai tidak hanya atas dasar penguasaan pengetahuan dan keterampilan, tetapi juga penguasaan sikap dan semangat kerja, kemampuan berkomunikasi, interpersonal, kepemimpinan, kerja sama tim, analisis permasalahan dan sintesis pemecahan masalah, disiplin, teknologi informasi, pemanfaatan komputer, fleksibilitas kerja, mampu mengelola kekaburan masalah, dapat bekerja dalam berbagai budaya, pemahaman globalisasi, terlatih dalam etika kerja, serta menguasai bahasa asing sebagai bahasa utama kedua.

Ketiga, perguruan tinggi diharapkan dapat menyelenggarakan program yang lebih humanis. Makna humanis dalam hal ini memberi peluang yang lebih besar bagi anggota masyarakat untuk dapat memperoleh manfaat dari penyelenggaraan pendidikan, jaminan mutu pendidikan, dan kegayutan kebutuhan masyarakat, menjawab pertanyaan terhadap persamaan hak, pemenuhan perspektif internasional, biaya pendidikan yang sepadan. Keempat, kurikulum sebagai pedoman penyelenggaraan program studi harus dapat menjaga keserasian antara program yang diselenggarakan dengan aspirasi masyarakat. Hal ini dapat ditempuh dengan cara meniadakan ketidakterpautan dan menghindarkan beban berlebihan proses pembelajaran, tetapi secara umum dapat mencirikan tugas khusus dan misi yang diembannya untuk setiap jenjang pendidikan.

Kelima, penyelenggaraan pendidikan tinggi diharapkan mampu menampung politisasi pendidikan, kebutuhan belajar sepanjang hayat, internasionalisasi pendidikan tinggi dalam makna reconvergent phase of education (Edward, 1995). Mengingat potensi dampak negatif yang begitu besar yang dihadapi di bidang pendidikan nilai di pendidikan tinggi maupun pengembangan perguruan tinggi, maka globalisasi merupakan tantangan cukup besar yang sedang dan akan dihadapi untuk masa-masa yang akan datang. Lebih lanjut, kita dapat mengatakan bahwa globalisasi merupakan tantangan strategis pendidikan tinggi dewasa ini. Strategis karena menyangkut kelangsungan hidup maupun kelangsungan misi yang diemban oleh pendidikan tinggi. Oleh karena itu, sudah seharusnya kita terutama yang berkecimpung di pendidikan tinggi mengantisipasi kemungkinan-kemungkinan yang akan terjadi di masa depan. Mari berbenah 
merapatkan barisan meluruskan sof untuk menyongsong hari depan yang penuh ketidakpastian. Yang lalu telah tercapai yang baru mari kita gapai.

Dengan demikian, era globalisasi adalah tantangan besar bagi dunia pendidikan. Dalam konteks ini, berbagai tantangan pendidikan dalam menghadapi globalisasi, pertama, tantangan untuk meningkatkan nilai tambah, yaitu bagaimana meningkatkan produktivitas kerja nasional serta pertumbuhan dan pemerataan ekonomi, sebagai upaya untuk memelihara dan meningkatkan pembangunan berkelanjutan (continuing development). Kedua, tantangan untuk melakukan riset secara komprehensif terhadap terjadinya era reformasi dan transformasi struktur masyarakat, dari masyarakat tradisional-agraris ke masyarakat modern-industrial dan informasi-komunikasi, serta bagaimana implikasinya bagi peningkatan dan pengembangan kualitas kehidupan SDM (Edward, 1995)

Ketiga, tantangan dalam persaingan global yang semakin ketat, yaitu meningkatkan daya saing bangsa dalam menghasilkan karya-karya kreatif yang berkualitas sebagai hasil pemikiran, penemuan dan penguasaan ilmu pengetahuan, teknologi dan seni. Keempat, tantangan terhadap munculnya invasi dan kolonialisme baru di bidang iptek, yang menggantikan invasi dan kolonialisme di bidang politik dan ekonomi. Semua tantangan tersebut menuntut adanya SDM yang berkualitas dan berdaya saing di bidang-bidang tersebut secara komprehensif dan komparatif yang berwawasan keunggulan, keahlian profesional, berpandangan jauh ke depan (visioner), rasa percaya diri dan harga diri yang tinggi serta memiliki keterampilan yang memadai sesuai kebutuhan dan daya tawar pasar.

Kemampuan-kemampuan itu harus dapat diwujudkan dalam proses pendidikan yang berkualitas, sehingga dapat menghasilkan lulusan yang berwawasan luas, unggul dan profesional, yang akhirnya dapat menjadi teladan yang dicita-citakan untuk kepentingan masyarakat, bangsa dan negara. Pertanyaan selanjutnya, apakah yang harus dilakukan oleh dunia pendidikan? Untuk menjawabnya, agaknya kita perlu menengok kerangka pendidikan dalam konteks kenasionalan. Sehingga kita bisa menyiapkan strategi yang tepat menghadapi sebuah tantangan sekaligus peluang tersebut. Secara kuantitas, perkembangan jumlah peserta didik pendidikan formal Indonesia mulai dari tingkat Taman Kanak-kanak hingga jenjang perguruan tinggi mengalami kemajuan yang cukup signifikan.

Namun secara kualitas masih tertinggal jauh ketimbang negara-negara lain, baik negara-negara maju, maupun negara-negara anggota ASEAN sekalipun (Ibe, 1995). Institusi pendidikan dituntut mampu menjamin kualitas lulusannya sesuai dengan standar kompetensi global paling tidak mampu mempersiapkan anak didiknya terjun bersaing dengan para tenaga kerja asing, sehingga bisa mengantisipasi membludaknya pengangguran terdidik. Di sini harus diakui, lembaga-lembaga pendidikan ternyata belum siap menghadapi era pasar bebas. Masih banyak yang harus dibenahi; apakah sistemnya ataukah orang yang terlibat di dalam sistem tersebut. Pemerintah, sebagai pemegang kebijakan pendidikan seharusnya memberikan sumbangan yang besar dalam mensukseskan program pendidikan. 
Sebab di antara kelemahan-kelemahan sistem pendidikan di Indonesia adalah karena lemahnya politcal will pemerintah dalam menangani permasalahan pendidikan ini. Setidaknya ada sembilan titik lemah dalam aplikasi sistem pendidikan di Indonesia: 1 . titik berat pendidikan pada aspek kognitif; 2. pola evaluasi yang meninggalkan pola pikir kreatif, imajinatif, dan inovatif; 3. sistem pendidikan yang bergeser (tereduksi) ke pengajaran; 4. kurangnya pembinaan minat belajar pada siswa; 5. kultur mengejar gelar (title) atau budaya mengejar kertas (ijazah); 6. praktik dan teori kurang berimbang; 7 . tidak melibatkan semua stake holder, masyarakat, institusi pendidikan, dan pemerintah; 8. profesi dosen sekedar profesi ilmiah, bukan kemanusiaan; 9. problem nasional yang multidimensional dan lemahnya political will pemerintah.

Untuk mengantisipasi berbagai kelemahan pendidikan tersebut, diperlukan kerjasama pelbagai pihak. Tidak hanya institusi pendidikan tetapi pemerintah juga harus serius dalam menangani permasalahan ini agar SDM Indonesia memperoleh rating kualitas pendidikan yang memadai. Untuk itu hendaknya dilakukan hal-hal sebagai berikut: pertama, orientasi pendidikan harus lebih ditekankan kepada aspek afektif dan psiko motorik. Artinya, pendidikan lebih menitikberatkan pada pembentukan karakter peserta didik dan pembekalan keterampilan atau skill, agar setelah lulus mereka tidak mengalami kesulitan dalam mencari pekerjaan daripada hanya sekadar mengandalkan aspek kognitif (pengetahuan). Kedua, dalam proses belajar mengajar guru harus mengembangkan pola student oriented sehingga terbentuk karakter kemandirian, tanggung jawab, kreatif dan inovatif pada diri peserta didik. Ketiga, guru harus benar-benar memahami makna pendidikan dalam arti sebenarnya.

Tidak mereduksi sebatas pengajaran belaka. Artinya, proses pembelajaran peserta didik bertujuan untuk membentuk kepribadian dan mendewasakan siswa bukan hanya sekedar transfer of knowledge tapi pembelajaran harus meliputi transfer of value and skill, serta pembentukan karakter (character building). Keempat, perlunya pembinaan dan pelatihan-pelatihan tentang peningkatan motivasi belajar kepada peserta didik sehingga anak akan memiliki minat belajar yang tinggi. Kelima, harus ditanamkan pola pendidikan yang berorientasi proses (process oriented), di mana proses lebih penting daripada hasil. Pendidikan harus berjalan di atas rel ilmu pengetahuan yang substantif. Oleh karena itu, budaya pada dunia pendidikan yang berorientasi hasil (formalitas), seperti mengejar gelar atau titel di kalangan praktisi pendidikan dan pendidik hendaknya ditinggalkan. Yang harus dikedepankan dalam pembelajaran kita sekarang adalah penguasaan pengetahuan, kadar intelektualitas, dan kompetensi keilmuan dan keahlian yang dimilikinya. Keenam, sistem pembelajaran pada sekolah kejuruan mungkin bisa diterapkan pada sekolah-sekolah umum. Yaitu dengan menyeimbangkan antara teori dengan praktek dalam implementasinya.

Sehingga peserta didik tidak mengalami titik kejenuhan berfikir, dan siap manakala dituntut mengaplikasikan pengetahuannya dalam masyarakat dan dunia kerja. Ketujuh, perlunya dukungan dan partisipasi komprehensif terhadap praktek pendidikan, dengan melibatkan semua pihak yang berkepentingan terhadap dunia pendidikan terutama masyarakat sekitar sekolah, sehingga memudahkan akses pendidikan secara lebih luas ke kalangan masyarakat. 
Kedelapan, profesi guru/dosen seharusnya bersifat ilmiah dan benar-benar "profesional", bukan berdasarkan kemanusiaan. Maksudnya, guru memang pahlawan tanpa tanda jasa namun guru/dosen juga seyogianya dihargai setimpal dengan perjuangannya, karena itu gaji dan kesejahteraannya harus diperhatikan pemerintah. Kesembilan, pemerintah harus memiliki formula kebijakan dan konsistensi untuk mengakomodasi semua kebutuhan pendidikan. Salah satunya adalah memperhatikan fasilitas pendidikan dengan cara menaikan anggaran untuk pendidikan minimal 20-25\% dari total APBN.

Di sini diperlukan political will kuat dari pemerintah dalam menangani kebijakan pendidikan. Jika kita mau jujur, berbagai kelemahan pendidikan kita seperti disebutkan di atas, pada dasarnya bertitik tolak pada lemahnya SDM yang ada. Padahal, SDM merupakan faktor utama yang menjadi indikator kemajuan suatu bangsa, di samping faktor sumber daya alam (SDA) (hayati, non hayati, buatan), serta sumber daya ilmu pengetahuan dan teknologi. Keberhasilan negaranegara Barat adalah didukung oleh peningkatan kualitas SDM, dan hal itu berhubungan dengan pendidikan sebagai wahana pembentukan SDM. Jadi, permasalahan lemahnya SDM Indonesia pada dasarnya berawal dari rendahnya tingkat pendidikan, lemahnya keahlian dan manajemen serta kurangnya penguasaan teknologi. Lemahnya SDM menyebabkan Indonesia kurang mampu bersaing dengan negara-negara lain, padahal secara fisiografis Indonesia termasuk negara yang memiliki kekayaan alam melimpah tetapi sayangnya tidak dikelola dengan baik karena kualitas SDM-nya yang kurang mendukung.

Sistem pendidikan sangat bergantung pada mutunya, seperti juga halnya barang dikatakan berkualitas dan mempunyai nilai jual yang tinggi karena memiliki mutu yang bagus. Ironis memang jika kita melihat nasib institusi pendidikan di Indonesia berdasarkan mutu pendidikan yang berada pada urutan terakhir di antara 12 negara Asia yang diteliti oleh The Political and Eonomic Risk Consultancy (PERC) tahun 2001, jauh di bawah Vietnam (6). Hasil survei PERC itu (lihat table 1) mengacu pada tingkat kualitas lulusan pendidikan kita, dengan argumentasi, untuk mendapatkan tenaga kerja berkualitas tentunya sistem pendidikannya pun harus berkualitas. Sistem pendidikan yang tidak berkualitas mempengaruhi rendahnya SDM yang dihasilkan, yang pada gilirannya tidak mampu membawa bangsa ini "duduk sama rendah dan berdiri sama tinggi" dengan bangsa lain. Lemahnya SDM pendidikan sebagai ekses sistem pendidikan yang tidak berkualitas, memunculkan fenomena masyarakat pekerja (worker society) bak jamur di musim hujan. Ini tentu berbeda dengan sistem pendidikan yang baik, yang memproduksi employee society. Secara ringkas ditampilkan sebagian peringkat universitas di dunia.

Selanjutnya, Toffler (1972) mengatakan, employee dan worker itu berbeda. (1) employee memiliki ciri untuk terus meningkatkan kemampuan teknis termasuk keterampilannya, sedangkan worker menggunakan keterampilan dan pengetahuan yang tetap; (2) employee dapat mengendalikan alat (mesin), sedangkan worker relatif dikendalikan oleh mesin; (3) mesin berkhidmat kepada employee, sedangkan worker berkhidmat kepada mesin; (4) employee pada dasarnya tidak perlu diawasi hanya perlu pembagian tanggung jawab, sedangkan worker harus diawasi melalui garis organisasi; dan (5) employee memiliki sarana produksi yaitu informasi, sedangkan 
worker tidak memilikinya. Oleh karena itu, orientasi employee society harus dikedepankan dalam rangka mempersiapkan tenaga kerja ahli di bidang penguasaan teknologi. Karena pada milenium ketiga ini kita dihadapkan pada perubahan besar di bidang ekonomi, Iptek dan sosial budaya. Kita seharusnya belajar dari Jepang dan Korea Selatan. Walaupun kedua negara tersebut miskin sumber daya alam (SDA), tetapi karena dukungan SDM yang kuat, kedua negara Asia Timur itu menjadi pioneer ekonomi dunia, khususnya di kawasan Asia.

Tabel 1: Ranking Web of World Universities

\begin{tabular}{|l|l|l|}
\hline Rank & Universitas & Negara \\
\hline 1 & Massachusetts Institute of Technology & USA \\
\hline 16 & University of Tokyo & Jepang \\
\hline 77 & Australian National University & Australia \\
\hline 92 & National University of Singapore & Singapura \\
\hline 205 & Peking University & China \\
\hline 324 & Prince of Songkla University & Thailand \\
\hline 583 & UGM & Indonesia \\
\hline 599 & UI & Indonesia \\
\hline 770 & ITB & Indonesia \\
\hline 1000 & Universitas Airlangga & Indonesia \\
\hline
\end{tabular}

Sumber: Ranking Web of World Universities 2011

Dalam konteks ini, masyarakat Jepang menurut Sudjana (2000) memiliki lima karakteristik khusus dalam sikap dan prilaku yang dipandang sebagai akar kekuatan bangsanya, yaitu: pertama, emulasi. Yaitu hasrat dan upaya untuk menyamai atau melebihi orang lain. Orang Jepang, baik selaku perorangan atau sebagai warga negara memiliki dorongan untuk tidak ketinggalan oleh orang, kelompok, atau bangsa lain. Kedua, consensus. Yaitu kebiasaan masyarakat Jepang untuk berkompromi, bukan konfrontasi. Budaya kompromi ini menimbulkan rasa keterlibatan masyarakat yang kuat terhadap kepentingan bersama. Budaya inilah yang menjadi pengikat dasar (root binding) kehidupan masyarakat Jepang. Ketiga, futurism. Yaitu mempunyai pandangan jauh ke depan, masyarakat Jepang mempunyai keyakinan bahwa harkat individu akan naik apabila seluruh kelompok atau bangsa naik. Oleh karena itu kemajuan dan keberhasilan kelompok, masyarakat dan bangsa sangat diutamakan dalam upaya meningkatkan kemajuan individu. Keempat, kualitas. Mutu adalah jaminan kualitas. Artinya dalam setiap proses dan hasil produksi di Jepang, mutu menjadi faktor penarik (full factors). Kelima, kompetisi. Artinya sumber daya manusia dan produk bangsa Jepang memiliki keunggulan komparatif dan kompetitif dalam tata kehidupan dan tata ekonomi global.

Kemampuan bersaing pendidikan kita menghadapi era globalisasi ini sangat lemah dibandingkan dengan negara-negara lain. Hal ini disebabkan karena 
masih lemahnya sumber daya manusia (SDM) yang ada. Sebagai contoh kita bisa melihat Tenaga kerja Indonesia (TKI) maupun TKW yang "diekspor" adalah tenaga buruh, seperti: pembantu rumah tangga, perawat, buruh perkebunan, buruh bangunan, sopir dan pekerja kasar lainnya. Sedangkan tenaga kerja asing yang bekerja di Indonesia adalah kalangan pengusaha, investor dan pemilik perusahaan. Pekerja kita amat minim penguasaan pengetahuannya serta rendah kemampuan bahasa asingnya, terutama Bahasa Inggris.

Untuk melacak akar kelemahan SDM Indonesia ini bisa dilihat melalui wahana pendidikan. Dari sini secara logis dimunculkan pemikiran, untuk dapat bersaing dengan bangsa lain dalam memperebutkan lapangan kerja, maka yang harus dibenahi terlebih dahulu adalah sektor pendidikan. Pendidikan harus benarbenar diberdayakan oleh kita semua, sehingga nantinya, pendidikanlah yang akan mampu memberdayakan masyarakat secara luas. Masyarakat yang terberdayakan oleh sistem pendidikan memiliki keunggulan komparatif dan kompetitif dalam konteks persaingan global. Konsekuensinya, pendidikan harus dikonseptualisasikan sebagai suatu usaha dan proses pemberdayaan, yang benarbenar harus disadari secara kolektif, baik oleh individu, keluarga, masyarakat, lebih-lebih oleh pemerintah sebagai investasi masa depan bangsa.

Dengan demikian, pendidikan memegang peranan penting dan strategis dalam menghasilkan SDM yang akan membangun bangsa ini. Sikap ini tidak berarti mengecilkan peran sektor lain dalam pembangunan bangsa. Adanya sikap bahwa masa depan akan selalu penting dan strategis ini didasari oleh pertimbangan empirik bahwa selama ini dan juga untuk waktu yang akan datang, keberadaan sumberdaya manusia yang bermutu dalam arti seluas-luasnya akan semakin dibutuhkan bagi pembangunan bangsa. Kualitas SDM yang diiringi moralitas dan integritas kebangsaan yang kuat: tidak korup, jujur, kreatif, antisipatif dan memiliki visi ke depan diasumsikan akan mempercepat bangsa ini keluar dari krisis yang berlarut-larut. Sebagai perbandingan, dengan dukungan sumber daya manusia yang kuat, negara-negara jiran kita seperti Malaysia, Thailand dan Filipina mengalami kemajuan pesat dalam upaya keluar dari krisis seperti yang dialami bangsa kita. Bahkan untuk kasus Malaysia, negara ini mampu memulihkan (recovery) kondisi ekonominya tanpa perlu mengandalkan bantuan IMF.

Selanjutnya, dalam sektor ekonomi, perkembangan perekonomian nasional, regional dan internasional yang begitu pesat seperti pasar modal, bursa efek, AFTA, NAFTA, APEC dan kesepakatan-kesepakatan ekonomi internasional yang lain, saat ini dan ke depan, semua itu akan menjadi kebutuhan bangsa kita. Tatanan kehidupan bermasyarakat, berbangsa dan bernegara, juga akan mengalami pergeseran. Perilaku individualistik akan tumbuh lebih subur daripada rasa kebersamaan. Sementara itu, kehidupan demokratis akan lebih diterima masyarakat ketimbang perilaku yang otoriter. Perilaku egaliter secara vertikal dan horizontal akan lebih menonjol dibanding yang feodal dan paternalistik.

Keterbukaan (transparency) akan diterima masyarakat. Di sisi lain, semangat nasionalisme dan kesemestaan harus dapat membawa kemajuan bangsa. 
Janganlah alasan nasionalisme menjadikan bangsa tidak bisa maju dan berkembang. Sebaliknya, semangat kesemestaan tidak dijadikan alasan bangsa ini tercabik dan terinfeksi oleh virus globalisasi. Semua itu, sekali lagi, memerlukan peran signifikan dan antisipasi pendidikan, apakah pendidikan kita mampu mengakomodasi dan memberikan solusi dalam upaya memajukan dan memenangkan kompetisi global yang keras dan ketat, ataukah justru terbelenggu dan asyik dalam lingkaran globalisasi.

\section{Kesimpulan}

1. Penguasaan sains dan teknologi bangsa Indonesia masih relatif rendah, bila dibandingkan dengan negara-negara tetangga di Asia, hal tersebut disebabkan kualitas SDM bangsa Indonesia rendah sehingga mengakibatkan tingkat daya saing bangsa juga rendah. Oleh karena itu, peningkatan kualitas perguruan tinggi harus menjadi prioritas dalam pembangunan bangsa agar mampu melahirkan SDM yang unggul dan berdaya saing tinggi sehingga produktifitas menjadi tinggi.

2. Globalisasi dalam dunia pendidikan, adalah sebuah proses sejarah yang panjang. Terjadinya era globalisasi dalam dunia pendidikan, memberi dampak ganda yaitu dampak yang positif (menguntungkan) dan dampak yang negatif (merugikan). Dampak yang menguntungkan, adalah memberi kesempatan kerjasama yang seluas-luasnya di bidang pendidikan kepada negara-negara di dunia. Namun di sisi lain, jika Indonesia tidak mampu bersaing di bidang pendidikan dengan negara lain, karena kualitas SDM yang lemah misalnya, maka konsekuensinya akan merugikan bangsa Indonesia sendiri (dampak merugikan).

3. Tantangan perguruan tinggi di era global adalah ditandai dengan perkembangan ilmu pengetahuan dan teknologi yang penuh dengan persaingan. Cepat atau lambat, perguruan tinggi di Indonesia yang akan datang, harus menghadapi peningkatan kualitas perguruan tinggi selaku lembaga pendidikan yang harus menghasilkan SDM yang berkualitas dan memiliki keunggulan dalam berbagai aspek kehidupan. Perguruan tinggi merupakan salah satu subsistem pendidikan nasional yang tidak dapat dipisahkan dari subsistem lainnya baik di dalam maupun di luar sistem pendidikan.

4. Pendidikan Tinggi setidaknya mampu mengembangkan lima bentuk kecerdasan, yaitu kecerdasan intelektual, kecerdasan emosional, kecerdasan praktikal, kecerdasan sosial, dan kecerdasan spiritual dan moral. Kelima bentuk kecerdasan ini harus dikembangkan secara simultan. Jika berhasil dilakukakn dengan baik, akan menghasilkan mahasiswa dan lulusan yang bukan hanya cerdas secara intelektual, tetapi juga cerdas dalam hal lain. Dengan kata lain bahwa paradigma baru pendidikan nasional adalah pendidikan harus berpusat pada peserta didik. 


\section{Daftar Pustaka}

Beck, U. 2000. What is Globalization? Cambridge: Polity Press.

Effendi, Sofian. 2002. Revitalizing Higher Education for Sustainable Economic Growth. Paper Read at Indonesia-German Symphosium 2002. Aaachen: RWTH

Friedman, Thomas L. 2002. Memahami Globalisasi. Lexus dan Pohon Zaitun, Bandung: Penerbit ITB

Freire, Paulo. 1999. Menggugat Pendidikan. Yogyakarta: Pustaka Pelajar. 2000. Pendidikan Kaum Tertindas. Terj. Pedagogy of the Oppressed, Jakarta: LP3ES.

Giddens, Anthony. 1999. Runaway World-Bagaimana Globalisasi Merombak Kehidupan Kita. Jakarta: Gramedia Pustaka Utama.

Halwani, R. Hendra. 2002. Ekonomi Internasional dan Globalisasi Ekonomi. Jakarta: Penerbit Ghalia Indonesia.

Imron, Ali, J. 1996. Kebijakan Pendidikan di Indonesia, Proses, Produk dan Masa Depannya. Jakarta: Bumi Aksara.

Ibe, M.D. 1995. Science Education: Moving on to 21th Century. Paper presented at The Regional Workshop on Strategic Planning in Science and Mathematics Education. RESCAM, Penang-Malaysia.

Jarvis, Peter. 2001. Universities and Corporate Universities: The Higher Learning Industries in Globalization. London: Kogan Page Industries.

John Naisbitt and P. Aburdane. 1999. Megatrend 2000: A New Directions for 1990's. Avonbooks, N.Y.

Kurniawan, Khaerudin. 1999. "Arah Pendidikan Nasional Memasuki Milenium Ketiga", Suara Pembaharuan, Januari.

Toffler, Alvin. 1980. Future Shock. London: Pan Book Ltd.

Peterson, Christhoper \& E.P. Seligman, Martin. 2004. Character Strengths and Virtues: A Handbook of Classification, Oxford: Oxford University Press.

Raka, Gede. 2000. Pendidikan Beyond Competence, Makalah disampaikan pada Lokakarya 'Membangun Indonesia Abad 21' yang diselenggarakan oleh Majelis Guru Besar ITB Tanggal 12-13 Juli di Balai Pertemuan Ilmiah ITB.

Scott, P. (Ed.). 1988. The Globalization of Higher Education. Buckingham: Open University Press.

Lanqing, Li. 2005. Education for 1.3 Billion. China: Pearson Education and Foreign Language Teaching \& Research Press.

Natsir, M. 1978. Pendidikan Pengorbanan ke Pemikiran Primondialisme dan Nostalgia, Jakarta: Media Dakwah. 
Renner, K. Edward. 1995. The New Agenda for Higher Education. Calgary: Detselig Enterprises, Ltd. Scott, P. (Ed.). 1988. The Globalization of Higher Education. Buckingham: Open University Press.

Stiglitz, Joseph P. 2002. Globalization and Its Discontents. New York: W.W. Norton \& Company

Suardi, Rudi. 2001. Sistem Manajemen Mutu ISO 9000-2000: Penerapannya Untuk Mencapai TQM. Jakarta: PPM \& Rosdakarya.

Sudjana, HD. 2000. Manajemen Program Pendidikan. Bandung: Falah Production.

Tilaar, H.A.R. Kajian Kritis Sistem Pendidikan Nasional. Makalah disampaikan dalam Seminar Nasional "Mencari Paradigma Baru Pendidikan Nasional Memasuki Milenium III" dalam HUT PGRI di Jogjakarta.

UU No. 2 Tahun 1989 tentang Undang-Undang Sistem Pendidikan Nasional.

UU No. 20 Tahun 2003 tentang Sistem Pendidikan Nasional.

Yunus, Mahmud. 1978. Pokok-Pokok Pendidikan dan Pengajaran. Jakarta: Hidakarya Agung. 